\title{
The Re-emergence Of American Visceral leishmaniasis IN AN OLD FOCUS IN VENEZUELA. II. VECTORS AND PARASITES
}

\author{
FELICIANGELI M.D.*, RODRIGUEZ N.**, DE GUGLIELMO Z.** \& RODRIGUEZ A.**
}

\begin{abstract}
Summary :
As part of an epidemiological study in an old focus of American Visceral Leishmaniasis (AVL) in Venezuela (Guayabita, Aragua State), a longitudinal entomological survey Uanuary 1993-June 1994) was carried out. A total of 3,239 males and 6,043 females belonging to 11 phlebotomine sandfly species were collected. The two recognised vectors of AVL in the New World, Lutzomyia evansi and Lu. longipalpis were found to be sympatric. Lutzomyia evansi was the dominant species (86.4\%), almost ten fold times more abundant than Lu. longipalpis (10.6\%). The two species alternated seasonally: Lu evansi peaked at the end of the rainy season while Lu. longipalpis, almost virtually absent during such period, increased in the dry season. This species seems more greatly influenced by the temperature. Seven of 4,559 Lutzomyia evansi $(0.15 \%)$ and one of 353 Lu. longipalpis $(0.28 \%)$ were found positive for suprapyloric promastigotes. Using the polymerase chain reaction (PCR) with universal primers, all isolates were identified as Leishmania spp. Two cultures from Lu. evansi, IEVA/VE/93/UCNA-2 and IEVA/VE/93/UCNA-3, were established. k-DNA restriction analysis showed high homologies between these isolates and Leishmania chagasi. High hybridization signal with L. chagasi specific kDNA confirmed these results. These findings suggest that Lu. evansi may play a role as vector of visceral leishmaniasis in this area. The identity of the parasite carried by Lu. longipalpis needs to be confirmed.
\end{abstract}

KEY WORDS : American visceral leishmaniasis, AVL, vectors, Lutzomyia evansi, Lutzomyia longipalpis, Leishmania chagasi, Venezuela.
Résumé : RÉÉMERGENCE DE LA LEISHMANIOSE VISCÉRALE AMÉRICAINE DANS UN FOYER ANCIEN DU CENTRE-NORD DU VÉNÉZUELA. II. VECTEURS ET PARASITES

Une étude entomologique longitudinale (janvier 1993-juin 1994) a été réalisée dans le village de Guayabita, État Aragua, un foyer ancien de leishmaniose viscérale du centre-nord du Vénézuela $\left.110^{\circ} 16^{\prime} \mathrm{N}, 67^{\circ} 28^{\prime} \mathrm{W} ; 500 \mathrm{~m}\right)$. Au total, 3239 mâles et 6043 femelles appartenant à 11 espèces de phlébotomes ont été capturés en utilisant des pièges CDC et Shannon. Lutzomyia evansi et lu. longipalpis, les deux espèces reconnues comme vecteurs de leishmaniose viscérale dans le Nouveau Monde ont été rencontrées en sympatrie dans ce foyer. Lutzomyia evansi prédomine nettement $(86,4 \%)$ sur Lu. longipalpis $(10,6 \%)$. Les deux espèces se succèdent selon la saison : Lu. evansi domine à la fin de la saison des pluies alors que Lu. longipalpis, virtuellement absent à cette époque de l'année, augmente à la saison sèche; cette espèce serait fortement influencée par la température. Sept exemplaires sur 4559 Lutzomyia evansi $(0,15 \%)$ et un spécimen sur 353 Lu. longipalpis $(0,28 \%)$ étaient naturellement infectés par des promastigotes suprapyloriques. En utilisant la PCR avec des amorces universelles, toutes les souches isolées ont été identifiées comme Leishmania spp. La multiplication des parasites à partir du tube digestif de deux lu. evansi, IEVA/VE/93/UCNA-2 et IEVA/VE/93/UCNA-3 a été obtenue. L'analyse de restriction du k-DNA a montré une grande homologie entre les souches isolées et Leishmania chagasi. Un haut signal d'hybridation avec kDNA spécifique de Le. chagasi a confirmé ces résultats qui ont permis de conclure au rôle vecteur de Lu. evansi dans ce foyer. L'identité du parasite transporté par Lu. longipalpis doit être confirmée.

MOTS CLÉS : leishmaniose viscérale, vecteurs, Lutzomyia evansi, Lutzomyia longipalpis, Leishmania chagasi, Vénézuela.

been recorded in the files of the Department of Dermatology (1995). However, these figures are considered to be underestimated.

Lutzomyia longipalpis, the more widely distributed proved vector of AVL in the New World (see Young \& Duncan, 1994) was first incriminated as the putative vector of AVL in Agua Hedionda, Guárico State, Venezuela, by Amaral et al. (1961a, b, c). Its epidemiological importance in different foci was also established by Pifano (1969) who, in the temporal absence of $L u$. longipalpis, first suggested that $\mathrm{Lu}$. evansi might be responsible for the transmission on AVL in Isla de Margarita (Pifano \& Romero, 1964). Lutzomyia evansi which is distributed from Central America to Colombia, Peru and Venezuela, has been so far demonstrated as

\footnotetext{
- Universidad de Carabobo, Facultad de Ciencias de la Salud, BIOMED, Apdo 4873, Maracay, Venezuela.

". Instituto de Biomedicina, Universidad Central de Venezuela, Caracas.

Correspondence: M. Dora Feliciangeli.

Tel. : ++5843 332532 - Fax : ++58 43419997

E-mail: mdora@telcel.net.ve 
AVL vector only in San Andrés de Sotavento, northwestern Colombia, where Lu. longipalpis is not present (Travi et al., 1990, 1996).

This paper deals with the results of a longitudinal entomological study carried out in Guayabita village, an old endemic AVL focus in Venezuela where Lu. longipalpis and $L u$. evansi coexist. In 1992 a new visceral leishmaniasis case was registered there. Consequently, an epidemiological study on humans and dogs was carried out (Delgado et al., 1998). The objectives of this work were: 1 . to study the species composition and the adult sandfly population dynamics; 2 . to search for natural infection to Leishmania spp.; 3. to identify Leishmania spp. isolated from naturally infected sandfly species.

\section{MATERIALS AND METHODS}

\section{STUDY AREA}

T The Guayabita village, Aragua State, Venezuela is located in north-central Venezuela $\left(10^{\circ} 16^{\prime} \mathrm{N}\right.$; $67^{\circ} 28^{\prime} \mathrm{W} ; 500 \mathrm{~m}$ above sea level), at the foothill of the Cordillera de la Costa (Costal Mountain Range) and about $20 \mathrm{~km}$ from Maracay. This life zone is classified as premontane dry forest (annual mean temperature $=25^{\circ} \mathrm{C}$, annual average rainfall $=700-1000 \mathrm{~mm}$ ) Climate is markedly seasonal with six dry months (November-April) (Ewel \& Madriz, 1968). The population of Guayabita is constituted by 493 inhabitants living in 65 households. The epidemiological features of this community have been described elsewhere (Delgado et al., 1998).

\section{SANDFLY COLLECTIONS}

During 2-3 consecutive nights, between January 1993 and June 1994, sandfly fortnight collections were carried out within the patient's family farm. Sandfly captures began in January 1993 with a Shannon trap between 18:30 and 21:30 and one CDC trap placed indoors overnight. In May 1993 two additional CDC traps were placed in the chicken coop and in the hogpen from 19:00 to 07:00 h. After collection, males were kept in alcohol, females were washed in a weak detergent solution ( $2 \%)$, rinsed in distilled water, and then kept in Nunc vials (1.5 ml; 20-25 females/ each) in sterile $10 \%$ DMSO in PBS $\mathrm{pH}=7.4$ for cryopreservation in liquid nitrogen. All samples were transferred to the Centro Nacional de Referencias de Flebótomos, University of Carabobo, Maracay for counting, species identification and dissection.

To assess the temporal association between sandfly numbers and weather variables, weather data [mean temperature (Tx), minimum temperature (Tmin), maximum temperature $(\operatorname{Tmax})$, mean relative humidity $(\mathrm{RHx})$,

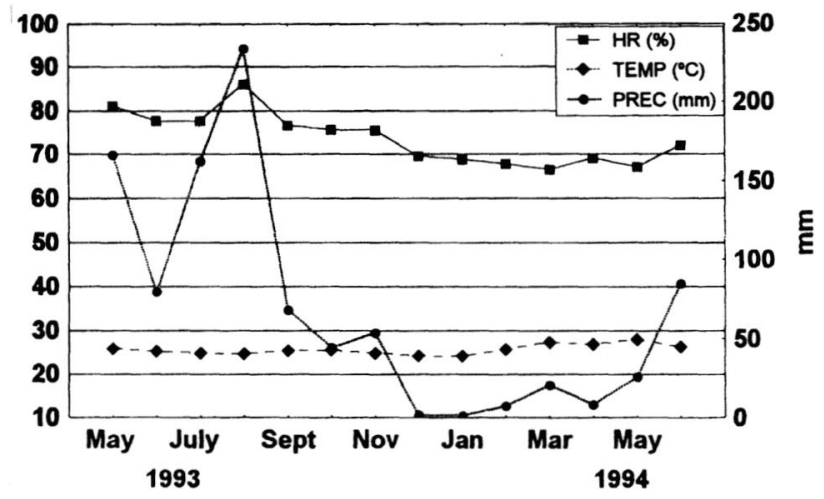

Fig. 1. - Monthly climate data recorded in the meteorological station of the Venezuelan Air Force in Maracay, $20 \mathrm{~km}$ away from the study village Guayabita.

minimum relative humidity (RHmin), maximum relative humidity (RHmax) and rainfall] recorded during the same period of collections at the meteorological station in Maracay, were obtained from the Department of Meteorology of the Venezuelan Air Force (Fig. 1).

\section{SANDFLY DATA ANALYSIS}

Sandfly collections were determined as number of sandflies per night per trap. As no normal distribution was observed for sandfly numbers (KolmogorovSmirnov one sample test: $\operatorname{Dmax}=0.37103 ; P<0.01$ ), Mann-Witney $U$ test was used to compare this variable between species and sexes and the Kruskall-Wallis test was used to compare numbers obtained with Shannon trap, CDC in chicken coop and CDC in hog-pen (May 1993-June 1994) and among months (May 1993February 1994). These analysis were only applied to Lu. evansi and Lu. longipalpis, using the STATISTICA package (Statsoft 1993). A Canonical Correspondence Analysis (Ter Braak, 1986) was also performed using the CANOCO package (Ter Braak, 1987-1992), to detect relationship between species abundance and environmental factors.

\section{SANDFLY IDENTIFICATION, SEARCH FOR NATURAL FLAGELLATE INFECTION AND LEISHMANIA SPP IDENTIFICATION}

In the laboratory, male sandflies were clarified and mounted for specific identification. The technique for searching natural infection was described previously (Feliciangeli et al., 1994). When flagellates were seen, culture was performed on blood agar base medium and, after multiplication, total DNA was extracted and analyzed as previously reported (Barrios et al., 1994). Comparison of the restriction patterns was obtained using international reference strains from both subgenus Viannia and Leishmania, listed in Table I. 


\begin{tabular}{|c|c|c|}
\hline Strain designation & Classification & Abbreviation \\
\hline MHOM/BZ/82/BEL21 & L. (L.) mexicana & BEL21 \\
\hline MHOM/BZ/62/M379 & L. (L.) mexicana & M379 \\
\hline MHOM/VE/83/H-78 & L. (L.) venezuelensis & $\mathrm{H} 78$ \\
\hline IFLA/BR/67/PH8 & L. (L.) amazonensis & PH8 \\
\hline MHOM/VE/76/LL1 & L. (L.) pifanoi & LL1 \\
\hline MHOM/BR/75/M2903 & L. (V.) braziliensis & M2903 \\
\hline $\mathrm{MHOM} / \mathrm{BR} / 75 / \mathrm{M} 4147$ & L. (V.) guyanensis & M4147 \\
\hline MHOM/PE/84/LC26 & L. (V.) peruviana & LC26 \\
\hline MHOM/BR/81/M6426 & L. (V.) lainsoni & M6426 \\
\hline IHR/CO/85/LC500 & L. (V.) colombiensis & LC500 \\
\hline MHOM/PA/71/LS94 & L. (V.) panamensis & LS94 \\
\hline MHOM/VE/76/JAP78 & L.(L.) garnhami & JAP78 \\
\hline MHOM/TN/80/IPT1 & L. (L.) infantum & IPT1 \\
\hline MHOM/BR/69/PP75 & L. (L.) chagasi & PP75 \\
\hline MHOM/IN/80/DD8 & L. (L.) donovani & DD8 \\
\hline MCAV/BR/45/L88 & L. (L.) enriettii & L88 \\
\hline
\end{tabular}

Table I. - Leishmania international reference strains used for characterization of isolates from $L u$. evansi collected in Guayabita, Venezuela.

The polymerase chain reaction (PCR), was performed using universal primers (Rogers et al., 1990), and L. donovani complex specific primers. kDNA hybridization was performed as previously described (Rodriguez et al., 1994).

\section{RESULTS}

\section{SANDFLY DATA}

A total of 9,282 sandflies (3,239 males and 6,043 females) of 11 phlebotomine sandfly species, six of them anthropophilic, were collected (Table II). Lutzomyia evansi numbers were signifi- cantly higher than $L u$. longipalpis ( $U=40086.50$; $P<0.001)$. A significant difference was found between sexes of Lu. evansi ( $U=13732.50 ; P=0.0268)$ but not between sexes of Lu. longipalpis $(U=14787.00 ; P=$ 0.2772). The Shannon trap was highly efficient for collecting $L u$. evansi, while the CDC trap placed in the chicken coop collected the highest number of $\mathrm{Lu}$. longipalpis. Monthly sandfly abundance varied significantly $\left(\chi^{2}=67.465 ; \mathrm{df}=11 ; P<0.0001\right)$. Figure 2 shows the adult population dynamics of females and males of Lu. evansi and Lu. longipalpis collected with all methods.

The Canonical Correspondence Analysis results are given in Table III. Lutzomyia longipalpis showed the highest score, indicating that this is the species which is more greatly influenced by the environmental variables, whereas $L$ u. evansi seems not to be affected by any specific abiotic factor. For the former species, the three temperature measurements exert a positive influence (the mean temperature exhibiting the greatest effect), whereas the relative humidity appears to be negatively correlated, the effect of mean values being the highest. Rainfall does not show a high score, however, it happened to be negatively correlated as well.

\section{LEISHMANIA SEARCH AND IDENTIFICATION}

Results of female dissections are given in Table IV. The highest infection rate of $L u$. evansi was found in October, when this species presented the highest density. The infected specimen of Lu. longipalpis was caught in June 1993. In all flies parasites were located in the midgut. Two cultures from $L u$. evansi (IEVA/ VE/93/UCNA-2 and IEVA/VE/93/UCNA3) were established in NNN medium with gentamycine. Using the

\begin{tabular}{|c|c|c|c|c|c|c|c|c|c|c|}
\hline \multirow[b]{3}{*}{ Species } & \multicolumn{2}{|c|}{ Shannon trap } & \multicolumn{2}{|c|}{ House } & \multicolumn{2}{|c|}{ Pigpen } & \multicolumn{2}{|c|}{ Chicken coop } & \multirow[b]{3}{*}{ Total } & \multirow[b]{3}{*}{$\%$} \\
\hline & \multicolumn{4}{|c|}{ January 1993-June 1994} & \multicolumn{4}{|c|}{ May 1993-June 1994} & & \\
\hline & Males & Females & Males & Females & Males & Females & Males & Females & & \\
\hline${ }^{*} L$. evansi & 2,075 & 4,894 & 4 & 9 & 188 & 375 & 219 & 252 & 8,016 & 86.36 \\
\hline${ }^{*}$ L. longipalpis & 189 & 97 & 5 & 0 & 27 & 32 & 399 & 235 & 984 & 10.60 \\
\hline${ }^{*} L$. gomezi & 35 & 10 & & & 4 & 6 & 5 & 4 & 64 & 0.69 \\
\hline L. dubitans & 36 & 37 & 1 & 0 & 12 & 8 & 38 & 38 & 170 & 1.83 \\
\hline L. trinidadensis & & 1 & & & & 14 & & 15 & 30 & 0.32 \\
\hline L. cayennensis & & 2 & & & & 3 & 1 & 3 & 9 & 0.10 \\
\hline L. rangeliana & 1 & 1 & & & & & & & 2 & 0.02 \\
\hline L. atroclavata & & & & & & 2 & & & 2 & 0.02 \\
\hline${ }^{*} L$. lichyi & & & & & & 2 & & & 2 & 0.02 \\
\hline${ }^{*}$ L. migonei & & & & & & & & 1 & 1 & 0.01 \\
\hline${ }^{*}$ L. panamensis & & 2 & & & & & & & 2 & 0.02 \\
\hline Total & 2,336 & 5,044 & 10 & 9 & 231 & 442 & 662 & 548 & 9,282 & 100,00 \\
\hline
\end{tabular}

* antropophilic species.

Table II. - Total sandfly species collected in a restricted focus of visceral leishmaniasis. Guayabita, Aragua State, Venezuela. 


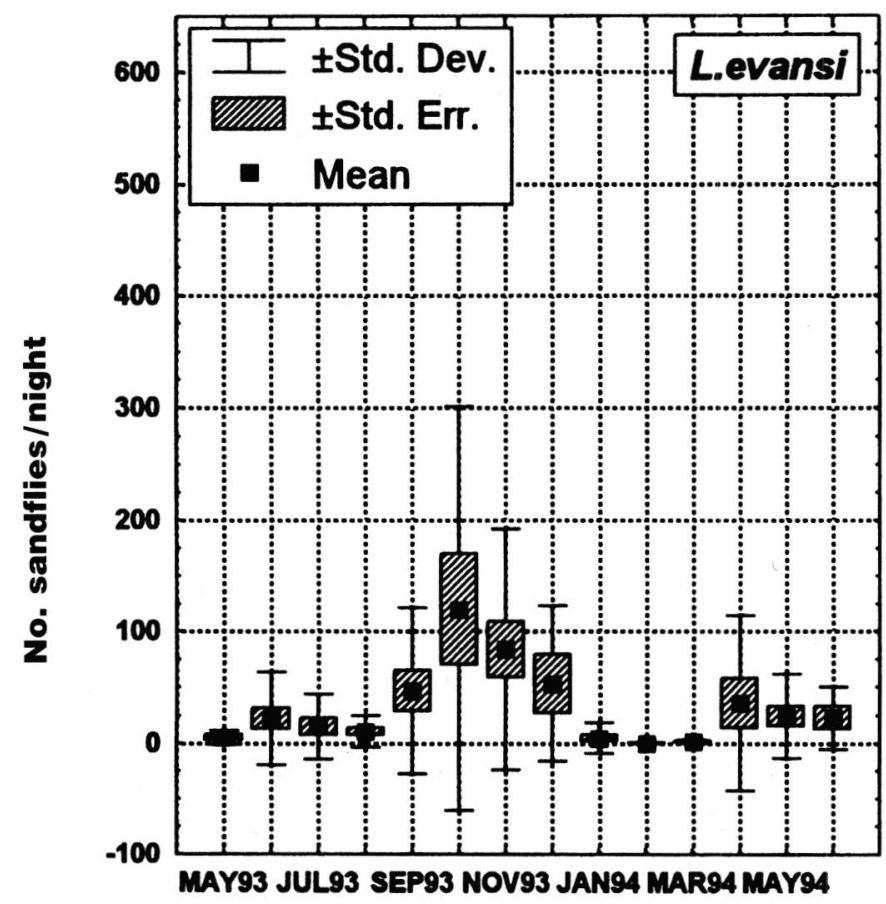

males

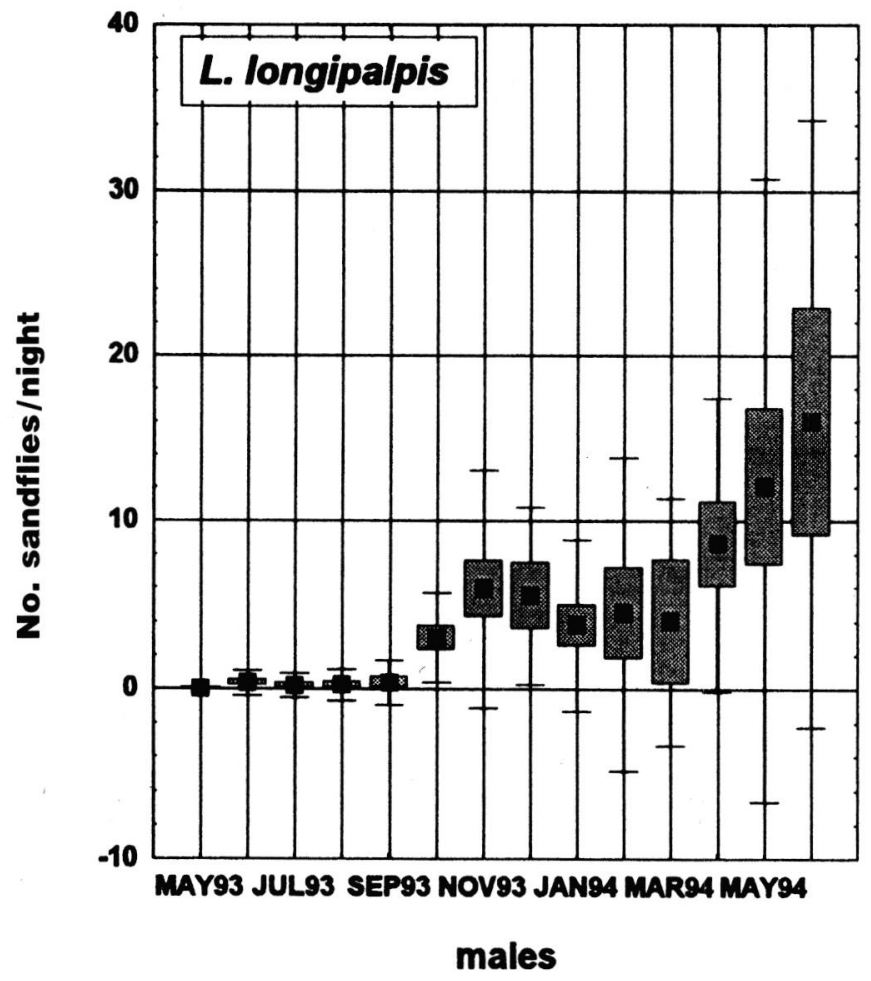

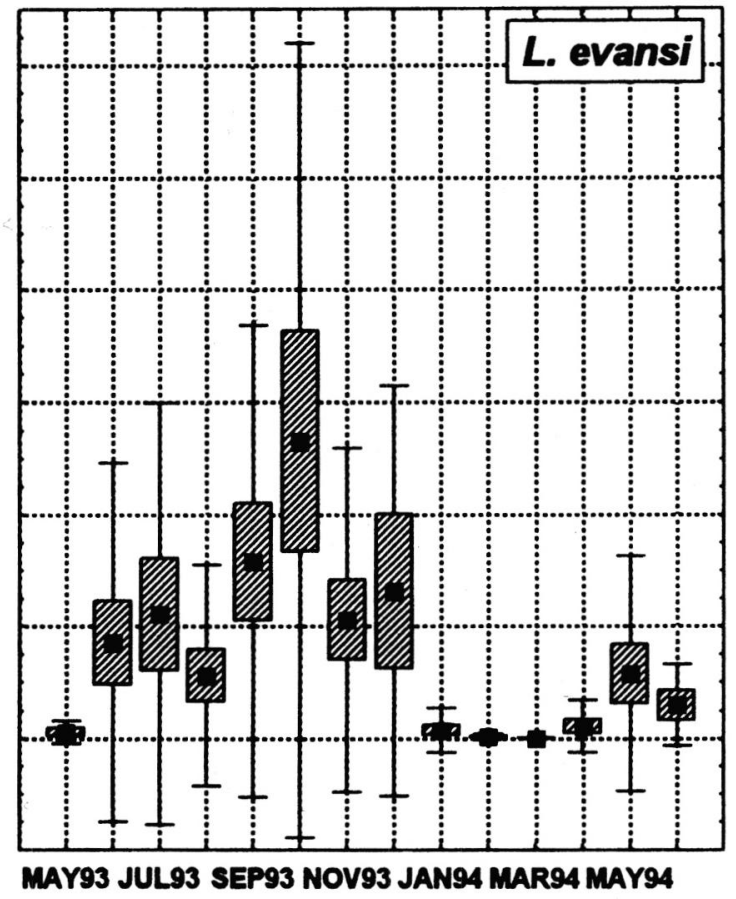

females

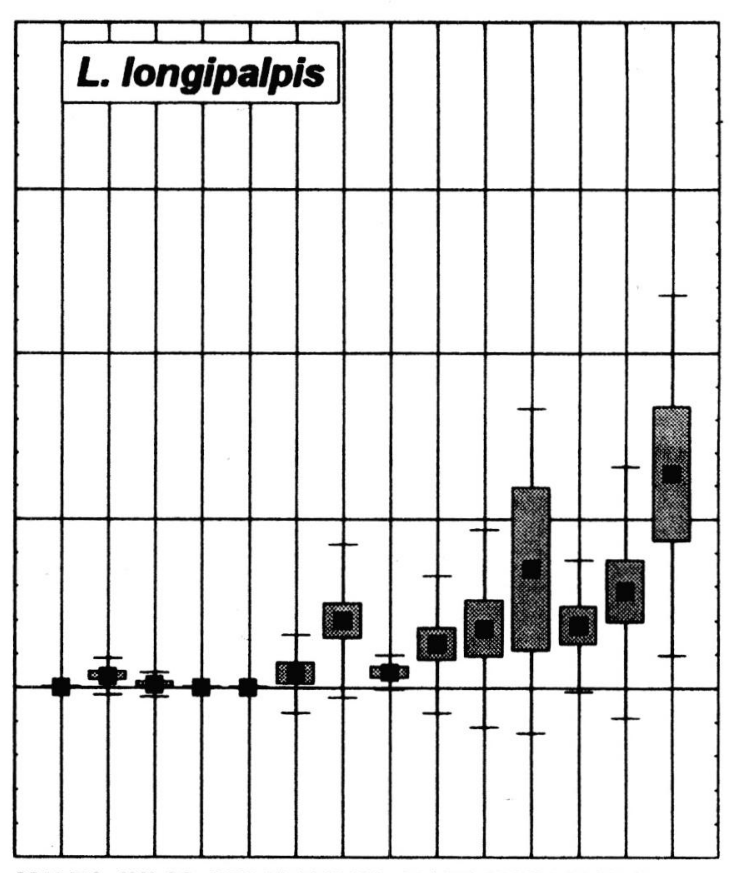

MAY93 JUL93 SEP93 NOV93 JAN94 MAR94 MAY94

females

Fig. 2. - Adult population dynamics of $L u$. evansi and $L u$. longipalpis in an endemic focus of AVL, Guayabita, Venezuela. 


\begin{tabular}{lc}
\hline \multicolumn{1}{c}{ Eigenvalue } & Axe 1 \\
\hline \multicolumn{1}{c}{0.133} \\
\hline Cumulative percentage Variance: & $68,6 \%$ \\
Of species data & $100 \%$ \\
Of species-environment relation & \\
\hline Species scores: & -0.0978 \\
L. evansi & 1.3622 \\
L. longipalpis & 0.6663 \\
Environmental variables scores: & 0.6164 \\
Mean Temperature & 0.4028 \\
Maximum Temperature & -0.6592 \\
Minimum Temperature & -0.5957 \\
Mean Relative Humidity & -0.5218 \\
Maximum Relative Humidity & -0.3259 \\
Minimum Relative Humidity & \\
Precipitation &
\end{tabular}

Table III. - Results of the Canonical Correspondence Analysis performed on two sandfly species, vectors of visceral leishmaniasis, and seven environmental variables, in Guayabita village, Venezuela.

PCR technique with universal primers, all isolates from sandfly females (seven Lu. evansi and one Lu. longipalpis) showed a 120 bp product characteristic of Leishmania spp (results not shown).

k-DNA restriction analysis (Fig. 3) showed high homologies between the isolates IEVA/VE/93/UCNA2 and IEVA/VE/93/UCNA-3 and L. chagasi, minor homologies were observed with $L$. donovani and $L$. infantum. However no homologies were observed with L. (Viannia) and others members of the L. (Leish-

\begin{tabular}{lrrllll}
\hline & $\begin{array}{c}\text { Total } \\
\text { dis- } \\
\text { sected }\end{array}$ & $\begin{array}{c}\text { L. } \\
\text { evansi }\end{array}$ & \% (n) & $\begin{array}{c}\text { L. } \\
\text { longi- } \\
\text { palpis }\end{array}$ & \% (n) \\
\hline Shannon trap & 4,807 & 3,980 & $0.15(6)^{*}$ & 86 & 0 \\
Pigpen & 385 & 318 & 0 & 32 & 0 \\
Chicken coop & 548 & 252 & $0.40(1)^{* *}$ & 235 & $0.42(1) \#$ \\
House & 9 & 9 & 0 & & \\
\hline \multicolumn{1}{c}{ Total } & $\mathbf{5 , 7 4 9}$ & $\mathbf{4 , 5 5 9}$ & $\mathbf{0 . 1 5}(\mathbf{7})$ & $\mathbf{3 5 3}$ & $\mathbf{0 . 2 8}(\mathbf{1})$ \\
\hline
\end{tabular}

* 01/06/1993 (two infected females;

05, 06, 18 and 19/10/1993 (four infected females).

** 02/02/1994 (one infected female).

\# 21/06/1993 (one infected female).

Table IV. - Total sandfly females dissected for search of Leishmania spp. and infected with promastigotes.

mania) subgenus. These results were confirmed after kDNA hybridization. Fig 4C shows the high hybridization signal between IEVA/VE/93/UCNA-2, IEVA/VE/93/UCNA-3 and L. chagasi $\mathrm{kDNA}$; an hybridization signal was not observed with $L$. braziliensis and $L$. mexicana $\mathrm{kDNA}$. The polymerase chain reaction (PCR) using specific Le. donovani primers showed at least three bands, one of those corresponding to a 805 bp, characteristic of $L$. donovani complex (Fig. 5).

Restriction fragment length polymorphism did not reveal differences between the IEVA/VE/93/UCNA-2 and IEVA/VE/93/UCNA-3 isolates and indicated no similarities between this group of isolates with other trypanosomatids tested (Crithidia sp, Endotrypanum,

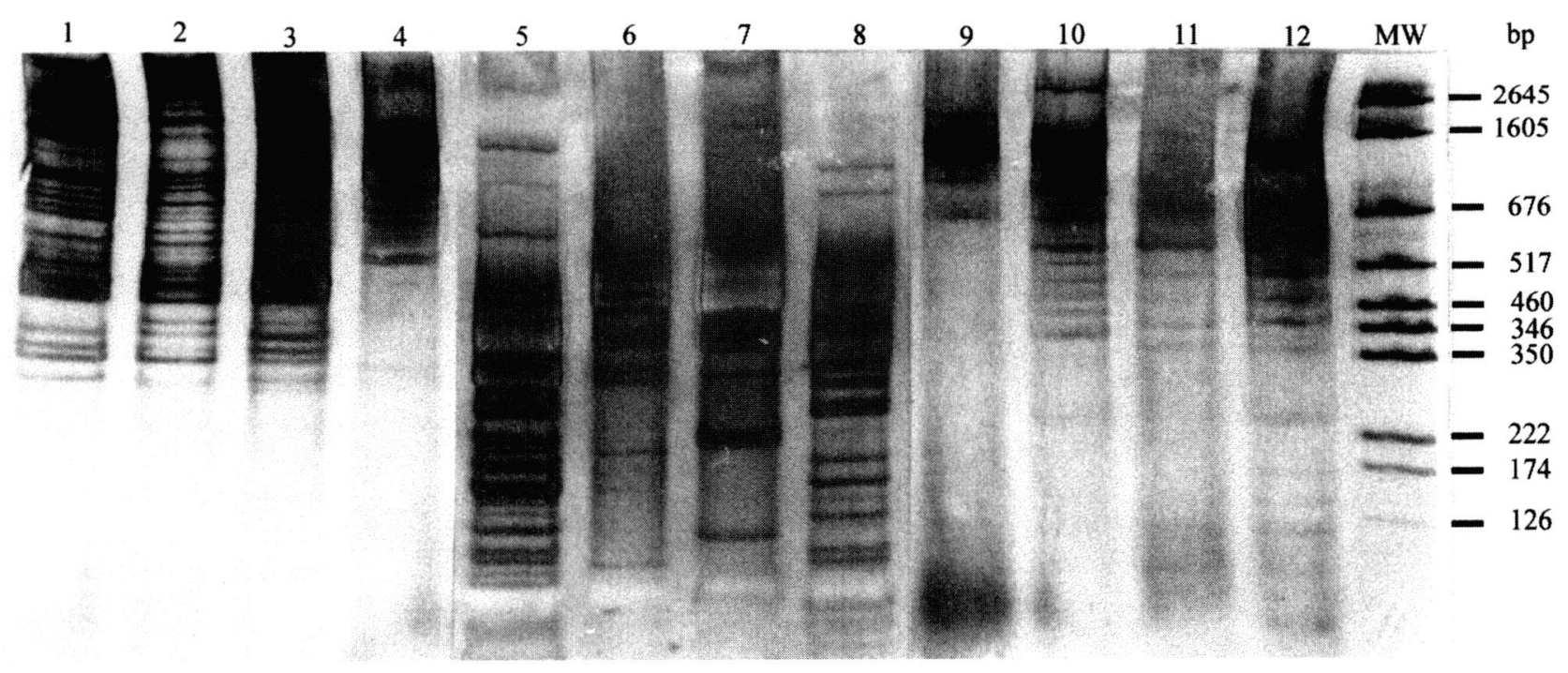

Fig. 3. - Kinetoplast DNA (kDNA) fragments patterns generated with the restriction enzyme Msp I. lane 1 - $L(L)$ chagasi (PP75); lane 2 - Eva2; Lane 3 - Eva3; lane 4 - L(V) braziliensis (M2903); lane 5 - L(L) amazonensis (PH8); lane 6 - L(V) colombiensis (LC500); lane 7 - L(L) pifanoi (LL1); lane $8-L(L)$ venezuelensis, lane $9-L(V)$ peruviana (LC26); lane $10-L(L)$ infantum (IPT1); lane $11-L(L)$ donovani (DD8); lane 12 $L(L)$ enrrietti (L88); lane 13 - Molecular weight markers pGEM (Promega). 


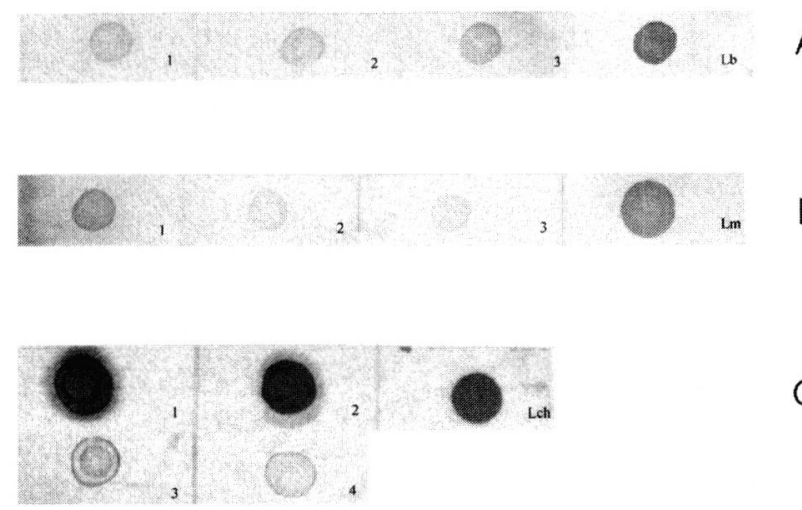

A

B

C

Fig. 4. - Dot-blot hybridization of kinetoplast DNA (kDNA) from the parasite culture. kDNA obtained from the isolates was hybridized to kDNA isolated from the International reference strains labelled to dATPdigoxigenin. A - L(V) braziliensis (M2903)-kDNA probe; number 1 : Eva2; 2 : Eva3; 3 : L(L) chagasi; 4 : M2903-kDNA. B - L(L) mexicana(PH8)-kDNA probe. 1 : Eva2; $2:$ Eva3; $3:$ L(L) chagasi; $4:$ L(L) amazonensis (PH8). C - L(L) chagasi-kDNA probe. 1 : Eva2; 2 : Eva3; L(L) chagasi (PP75); 3 : L(L) amazonensis (PH8); 4.- L(V) braziliensis (M2903).

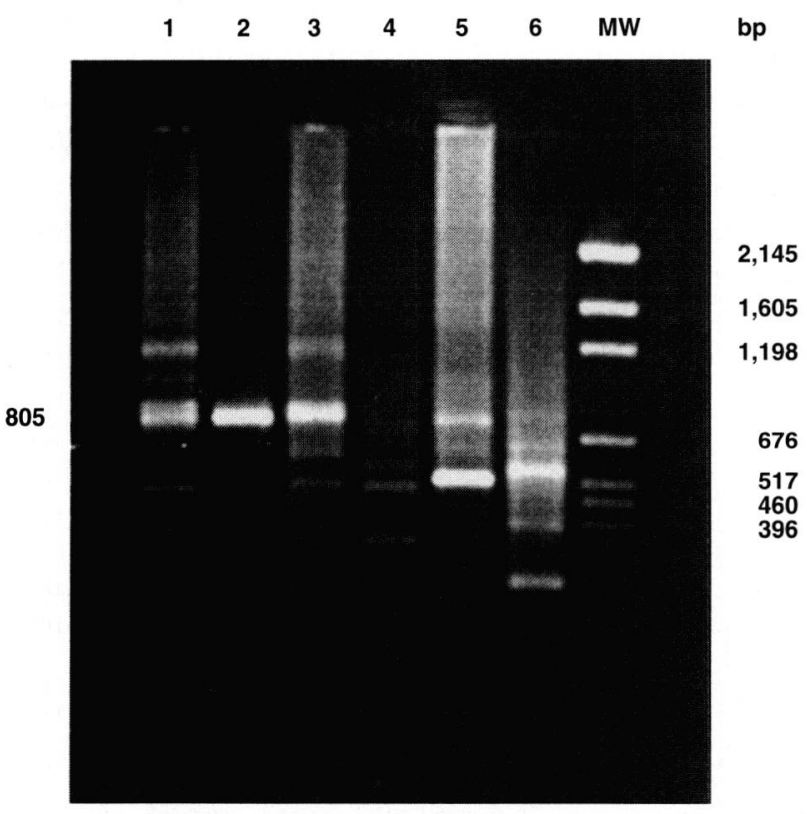

Fig. 5 - PCR products obtained after 35 cycles of amplification with AJS3/DB8 L. donovani species-specific primers. Lane 1 : Eva2; lane 2 : Eva3; lane 3 : L. chagasi (PP75); lane 4: L. donovani (DD8); lane 5 : L. infantum; lane 6 : Talisman 2 (Venezuela strain); MW : Molecular weight markers.

Sauroleishmania, L. herreri, L. hertigi, L. aristedesi). However, this type of analysis did not distinguish among the reference strains from each of the three complexes (L. (V.) braziliensis, L. (L.) mexicana and L. (L.) donovani) (data not shown).

\section{DISCUSSION}

Tnformation on the abundance and temporal distribution of phlebotomine sandfly vectors contributes L to the understanding of the epidemiology of the leishmaniases, to the prediction of transmission seasonality, and to assist in planning control strategies. When more than one putative vector coexist in the same area, these data are specially important. This work is the first one that deals with the concomitant population dynamics of $L u$. longipalpis and Lu. evansi, the two recognised vectors of American Visceral Leishmaniasis, a disease which has shown to be emerging in different foci in urban areas (Arias et al., 1996; Aguilar et al., 1998) and re-emerging in rural areas (Delgado et al., 1998) in the New World.

Both species were present throughout the year in Guayabita, a village with flourishing agriculture and animal breeding. The $L u$. evansi population overwhelmed the Lu. longipalpis population and alternated with it, peaking at the end of the rainy season (October 1993), while the low Lu. longipalpis population hardly increased at the end of the dry season (April-May 1994). This unimodal pattern of Lu. evansi was similar to that reported in San Andrés de Sotavento, Cordoba Department, Colombia (Travi et al., 1996) where the amount of rainfall was also similar, with a maximum precipitation of about $200 \mathrm{~mm}$. However, indoor collections of $L u$. evansi in Guayabita were extremely scarce when compared with those obtained with the same trapping method (CDC trap) in Colombia, even though differences were observed there between two villages in the same area (Vidales and El Contento). Unfortunately Travi et al. (1996) did not give data on the domestic fauna in each locality; we believe that the abundance of domestic animals around the house in Guayabita may be a key factor in determining the exophilic behaviour of $L u$. evansi. The population of $L u$. longipalpis in Guayabita was clearly different in size and fluctuation to the population in El Callejón, Cundinamarca Department, Colombia. In Guayabita the $L u$. longipalpis density was very low and the results of the canonical analysis allowed us to conclude that rainfall and relative humidity are determinant and negative factors in Lu. longipalpis density. On the contrary Lu. longipalpis was abundant and displayed a bimodal annual cycle positively related to humidity and rainfall in El Callejón (Morrison et al., 1995). However, rainfall was erratic and low in El Callejón, while in Guayabita it was continuous during June to September 1993, reaching up to $230 \mathrm{~mm}$. Comparison of population dynamics in different ecological situations is therefore of value to determine, for each climatic variable, the range in between the species is favoured and outside which it will be affected. Such information may not 
only help in predicting local vector occurrence and abundance; in addition, it may be useful to attempt an ecological approach to the stratification of the visceral leishmaniasis in the neotropics.

In this study both $L u$ evansi and Lu. longipalpis were found naturally infected with suprapyloric promastigotes in the same focus. The nature of two isolates from $L u$. evansi previously reported (Feliciangeli et al., 1993), was investigated using molecular techniques. Traditionally, parasites isolated from different sources have been identified using biochemical techniques such as zymodemes (Momen et al., 1993) and monoclonal antibodies (McMahon Pratt et al., 1985). However, during the last ten years the molecular techniques are in greater use due to their sensitivity and specificity for species and subspecies identification. These technique have allowed the identification of parasites from humans (Barker, 1987; Barker \& Butcher, 1993; Rodriguez et al., 1994) and vectors (Barrios et al., 1994) as well as taxonomic studies (Dujardin et al., 1993). The sensitivity of kDNA probes has been widely demonstrated (Ready et al., 1988; Barker \& Butcher, 1993). kDNA contains regions which vary in homology between the different species; some regions are very conserved whereas other areas are variable, and they are different between the different complexes. IEVA/VE/93/UCNA-2, IEVA/VE/93/UCNA-3 isolates and $L$. chagasi share large areas of homology while there are very short regions of homology with Le. braziliensis and Le. mexicana complexes and others trypanosomatidae such as T. cruzi and T. evansi. Concordance within different molecular techniques which are complementary to each other, allows us to characterise our isolates from $L u$. evansi as belonging to the L. donovani complex; moreover, the high homology with the L. chagasi $\mathrm{kDNA}$ suggests that these isolates are more similar to this group of parasites.

Though the suprapyloric Leishmania found in $\mathrm{Lu}$. longipalpis might have been L. chagasi, the rate of natural infection was higher in Lu. longipalpis $(0.28 \%)$ than in Lu. evansi. $(0.15 \%)$. However, the identity of the parasite carried by Lu. longipalpis, which in Venezuela often shares the same ecological habitats as Lu. evansi (Pifano \& Romero, 1964; Bendezu et al., 1995; Aguilar et al., 1998) needs to be confirmed.

The epidemiological situation in Venezuela seems more complicated than in Colombia where Lu. evansi and $L u$. longipalpis are responsible for AVL transmission in separate foci. Natural infection rates of $0.03 \%$ and $0.10 \%$ Lu. evansi to Le. chagasi were reported in two hamlets in San Andrés de Sotavento, where, despite intensive collections, Lu. longipalpis was never caught. (Travi et al., 1996). In El Callejón, where $L u$. evansi has not been found, Lu. longipalpis is considered the unique vector of AVL. The natural infection rates reported there in two different periods were $8.8 \%$ (Corredor et al., 1989) and $0.29 \%$ (Ferro et al., 1995). In both foci the parasites were identified using zymodemes. Strains from naturally infected opossums (Didelphis marsupialis) and sentinel dogs were also identified as L. chagasi in El Callejón, where the prevalence of infection among the inhabitants was $51.2 \%$ (Corredor et al., 1988). The low endemicity of the disease in Guayabita with $11.4 \%$ of leishmanin positive humans and $15.5 \%$ of seropositive dogs (Delgado et al., 1998) has not allowed, so far, the isolation and comparison with parasites from sand flies, humans and reservoir hosts. Further laboratory and field studies here and in other different defined ecotopes, are necessary in order to fully understand the vector-parasite relationship and the transmission dynamics of the AVL in Venezuela, looking for appropriate control strategies.

\section{ACKNOWLEDGEMENTS}

his work was funded by Fundacite Aragua (Pasa -17), the Commission of the European Community (Contract T*S3-CT93-0247) and the University of Carabobo (Project FCS-91-044). The technical assistance of Freddy Arias and Florencio Mendoza and the help of Alfredo Gutierrez in the statistical analysis are also acknowledged.

\section{REFERENCES}

Aguilar C.M., Fernandez E., Fernandez R., Cannova D.C., Ferrer E., Cabrera Z., Souza W.J.S. \& Coutinho S.G. Urban visceral leishmaniasis in Venezuela. Memorias do Instituto Oswaldo Cruz, 1998, 93, 15-16.

Amaral A.D.F., Torrealba J.W., Henriquez C.E., Kowalenko W. \& BARrios P.A. Studies on visceral leishmaniasis in Venezuela. Revista do Instituto de Medicina tropical de Sâo Paulo, 1961a, 3, 91-98.

Amaral A.D.F., Torrealba J.W., Henriquez C.E., Kowalenko W. \& BARrios P.A. Revisión sobre el kala-azar en Venezuela. Folia Clinica Biologica, 1961b, 30, 14-24.

Amaral A.D.F., Torrealba J.W., Henriquez C.E., KowalenKo W. \& Barrios P.A. Phlebotomus longipalpis Lutz \& Neiva, 1912, probable transmisor de la leishmaniasis visceral en Venezuela. Gaceta Médica de Caracas, 1961c, 70, 389-408.

Arias J.R., MonTeiro P.S. \& Zicker F. The reemergence of visceral leishmaniasis in Brazil. Emerging Infectious Diseases, 1996, 2, 145-146.

BARKER D.C. DNA diagnosis of human leishmaniasis. Parasitology Today, 1987, 3, 177-184.

BARKER D.C \& BUTCHER J. The use of DNA probes in the identification of Leishmania: Discrimination between isolates of Leishmania mexicana and Leishmania braziliensis complexes. Transactions of the Royal Society of Tropical Medicine and Hygiene, 1993, 77, 285-297 
Barrios M.A., Rodriguez N., Feliciangeli M.D., Ulrich M. Telles S., Pinardi M.E. \& Convit J. Coexistence of two species of Leishmania in the digestive tract of the vector Lutzomyia ovallesi. American Journal of Tropical Medicine and Hygiene, 1994, 5, 669-675.

Bendezu H., Moreno G., Villegas E. \& Oviedo M. Bionomía de vectores de leishmaniasis visceral en el Estado Trujillo, Venezuela. V. Preferencias alimentarias de poblaciones silvestres de Lutzomyia longipalpis y Lutzomyia evansi. Boletin de la Dirección de Malariología y Saneamiento Ambiental, 1995, 35 (Suppl 1), 45-52.

Corredor A., Gallego J.F., Tesh R., Morales A., Ferro de Carrasquilla C., Young D., Kreutzer R.D., Bishell J., Palau M.T., Caceres E. \& Pelaez D. Epidemiology of visceral leishmaniasis in Colombia. American Journal of Tropical Medicine and Hygiene, 1989, 40, 480-486.

Delgado O., Feliciangeli M. D., Gomez B., Alvarado J., Garcia L. \& BeLLO C. The re-emergence of American visceral leishmaniasis in an old focus in Venezuela: Present situation of human and canine infections. Parasite, 1998, 5, 317323.

Desjeux P. Information on the epidemiology and control of the Leishmaniases by country and territory. WHO/LEISH/91.30.

Dujardin J.C., Llanos-Cuentas A., Caceres A., Arana M., Dujardin J.P., Guerrini F. \& Arroyo J. Molecular karyotype variation in Leishmania (Viannia) peruviana. Indication of geographic population in Perú distributed along a NorthSouth cline. Annals of Tropical Medicine and Parasitology $1993,87,335-347$

Ewel J.J. \& MAdriz A. Zonas de vida de Venezuela. Memoria explicativa sobre el mapa ecológico. Editorial Sucre, Caracas. 1968, 264.

Feliciangeli M.D., Gomez B., Delgado O., Garcia L. \& Bello C. Leishmaniasis visceral en el caserío La Ganadería de Guayabita, estado Aragua Venezuela: Infección natural de Lutzomyia evansi (Diptera: Psychodidae) a Leishmania spp. Acta Científica Venezolana, 1993, 44 (Supl. 1), 262.

Feliciangeli M. D., Rodriguez N., Bravo A., Arias F. \& Guzman B. Vectors of cutaneous leishmaniasis in north-central Venezuela. Medical and Veterinary Entomology, 1994, 8, $317-$ 324 .

Ferro C., Morrison A., Torres M., Pardo R., Wilson M. \& Tesh R. Age structure, blood-feeding behavior and Leishmania chagasi infection in Lutzomyia longipalpis (Diptera: Psychodidae) at an endemic focus of visceral leishmaniasis in Colombia. Journal of Medical Entomology, 1995, 32, 605617 .

Martinez Niochet A. \& Pons A.R. Primer caso de kala-azar en Venezuela. Gaceta Médica de Caracas, 1941, 48, 329332 .

Mcmahon Pratt D., Bennett E., Grimaldi G. \& Jaffe Ch. Subspecies and species specific antigens of Leishmania mexicana characterized by monoclonal antibodies. Journal of Immunology, 1985, 143, 1935-1940.

Momen H., Cupolillo E. \& Grimaldi J.R. Population genetic of Leishmania in the New World. Current Trends in Leishmania. Research publication and Information Directorate (CSIR). A.N. Bhaduri Edit, New Delhi-India, 1993.
Morrison A.G., Ferro C., Pardo R., Torres M., Devlin B., WiLson M.L. \& TeSh R. Seasonal abundance of Lutzomyia longipalpis (Diptera: Psychodidae) at an endemic focus of visceral leishmaniasis in Colombia. Journal of Medical Entomology, 1995, 32, 538-548.

Pifano F. Algunos aspectos en la ecología y epidemiología de las enfermedades endémicas con focos naturales en el área tropical, especialmente en Venezuela. Ministerio de Sanidad y Asistencia Social (ed) Caracas, 1969.

Pifano F. \& Romero M.J. Investigaciones epidemiológicas sobre la leishmaniasis visceral en la Isla de Margarita, Edo. Nueva Esparta, Venezuela. Gaceta Médica de Caracas, 1964, 72, 425-430.

Ready P.D., Smith D.F \& Killick-Kendrick R. DNA hybridization on squash-blotted snaffles to identify both Phlebotomus papatasi and infecting Leishmania major. Medical and Veterinary Entomology, 1988, 2, 109-116.

Rogers M.R., Popper S.J. \& WIRTH D.F. Amplification of kinetoplast DNA as a tool in detection and diagnosis of Leishmania. Experimental Parasitology, 1990, 71, 267-275.

Rodriguez N., Guzman B., Rodas A., Takiff H., Bloom B. \& Convit J. Diagnosis of cutaneous leishmaniasis and species discrimination of parasites by PCR and hybridization. Journal of Clinical Microbiology, 1994, 32, 2246-2252

Rodriguez N, De lima H, Rodriguez A., Brewster \& Barker D.C. Genomic DNA repeat from Leishmania (Viannia) braziliensis (Venezuelan strain) containing simple repeats and microsatellites. Parasitology, 1997, 115, 349-358.

Statsoft. Statistica for Windows 4.0. 1993. Statsoft Inc.

Ter Braak C.J.F. Canonical correspondence analysis: a new eigenvector technique for multivariate direct gradient analysis. Ecology, 1986, 67, 1167-1179.

TER BRAAK C.J.F. CANOCO- $\alpha$ FORTRAN program for Canonical Community Ordination. Microcomputer Power, Ithaca, New York, USA 1987-1992.

Travi B.L., Velez J.D., Brutus L., Segura I., Jaramillo C. \& Montoya J. Lutzomyia evansi, an alternate vector of Leishmania chagasi in a Colombian focus of visceral leishmaniasis. Transactions of the Royal Society of Tropical Medicine and Hygiene, 1990, 84, 676-677

Travi B.L., Montoya J., Gallego J. Jaramillo C., Llano R. \& Velez I. Bionomics of Lutzomyia evansi (Diptera: Psychodidae) vector of visceral leishmaniasis in Northern Colombia. Journal of Medical Entomology, 1996, 33, 278285.

Young D.G. \& Duncan M.A. Guide to the identification and geographic distribution of Lutzomyia sandflies in Mexico, the West Indies, Central and South America (Diptera: Psychodidae). Memoirs of the American Entomologist Institute 54. 1994. Associated Publishers, Gainesville, Fl.

Reçu le 22 août 1998 Accepté le 23 janvier 1999 